\title{
UPAYA MENGEMBANGKAN KREATIVITAS SISWA TUNARUNGU KELAS VIII DALAM MENYELESAIKAN SOAL MATEMATIKA DENGAN MODEL PEMBELAJARAN AKTIF TIPE SNOW BALL PADA POKOK BAHASAN BANGUN RUANG SISI LENGKUNG DI SMPLB KERATON TAHUN PELAJARAN 2015/2016
}

\author{
Sugiyana
}

\begin{abstract}
Abstrak
Penelitian ini bertujuan untuk mengembangkan kreativitas siswa dalam menyelesaikan soal matematika pada pokok bahasan bangun ruang sisi lengkung dan meningkatkan hasil belajar siswa.

Subjek dalam penelitian ini adalah siswa Kelas VIII/B (Tunarungu) di SMPLB Keraton Martapura yang berjumlah 6 orang terdiri dari 4 orang laki-laki dan 2 orang perempuan. Data penelitian ini adalah pengembangan kreativitas siswa dalam menyelesaikan soal matematika pokok bahasan bangun ruang sisi lengkung. Teknik pengumpulan data yang dilakukan adalah observasi, catatan lapangan, review, dan tes yang dilakukan selama tiga kali putaran. Analisis data dalam penelitian ini dilakukan secara deskriptif kualitatif dengan metode alur.

Hasil penelitian ini menunjukkan adanya peningkatan dan mengembangkan kreativitas siswa dalam menyelesaikan soal matematika pokok bahasan bangun ruang sisi lengkung. Hal ini dapat dilihat dari mengkonstruksi soal ke dalam model matematika di akhir putaran mencapai $78.05 \%$, ketepatan menggunakan rumus untuk menyelesaikan soal di akhir putaran mencapai $92.68 \%$, dan kemampuan dalam proses perhitungan untuk mencari jawaban pada putaran terakhir mencapai $87.80 \%$. Penelitian ini menyimpulkan bahwa penggunaan pendekatan pembelajaran aktif tipe snow ball dapat meningkatkan kreativitas siswa dalam menyelesaikan soal matematika pokok bahasan bangun ruang sisi lengkung sehingga berdampak pada peningkatan hasil belajar siswa.
\end{abstract}

Kata Kunci: kreativitas, menyelesaikan soal, snow ball, bangun ruang sisi lengkung 
Upaya Mengembangkan Kreativitas Siswa Tunarungu Kelas VIII dalam Menyelesaikan Soal Matematika Dengan Model Pembelajaran Aktif Tipe Snow Ball Pada Pokok Bahasan Bangun Ruang Sisi Lengkung di SMPLB Keraton Tahun Pelajaran 2015/2016

\section{Pendahuluan}

Anak Luar Biasa/ALB yang juga dikenal dengan istilah Anak Berkebutuhan Khusus/ABK adalah anak-anak yang mengalami kelainan khusus baik fisik, mental, maupun sosialnya. Anak dengan kelainan khusus mempunyai kendala (hambatan) perkembangan sehingga memerlukan layanan pendidikan khusus. Sesuai dengan Undang-Undang Republik Indonesia No. 20 ayat (1). Dinyatakan bahwa "Pendidikan khusus merupakan pendidikan bagi peserta didik yang memiliki tingkat kesulitan dalam mengikuti proses pembelajaran karena kelainan fisik, emosional, mental, sosial, dan atau memiliki potensi kecerdasan dan bakat istimewa." (Bandi Delphie, 2007:55).

"Siswa tunarungu adalah seseorang yang mengalami kekurangan atau kehilangan kemampuan mendengar baik sebagian atau seluruhnya yang diakibatkan karena tidak berfungsinya sebagian atau seluruhnya alat pendengaran, sehingga ia tidak dapat menggunakan alat pendengarannya dalam kehidupan sehari hari yang membawa dampak terhadap kehidupannya secara kompleks". Oleh karena itu bagi siswa tunarungu harus dibantu dengan bahasa isyarat, agar mereka dapat berkomunikasi, baik menerima maupun menyampaikan kepada orang lain. (Somad dan Tati Herawati, 2004).

Matematika sebagai salah satu mata pelajaran yang diajarkan di sekolah pada jenjang pendidikan dasar, pendidikan menengah dan pendidikan tinggi memegang peranan penting. Berhasil tidaknya pencapaian dari tujuan pembelajaran matematika banyak bergantung pada proses belajar mengajar yang dialami siswa sebagai peserta didik dan guru sebagai pendidik. Salah satu indikasi terjadinya peningkatan kualitas belajar dan tercapainya tujuan pembelajaran dapat dilihat dari adanya peningkatan prestasi akademik siswa secara keseluruhan, mulai dari jenjang pendidikan dasar sampai dengan pendidikan tinggi. Salah satu cara yang dapat 
dilakukan untuk meningkatkan kualitas belajar siswa adalah dengan menerapkan model pembelajaran yang tepat (Aisyah, 2007).

Pembelajaran aktif adalah suatu pembelajaran yang mengajak peserta didik untuk belajar secara aktif. Dimana mereka yang mendominasi aktifitas pembelajaran. Dengan ini mereka secara aktif menggunakan otak, baik untuk menemukan ide-ide, memecahkan persoalan atau mengaplikasikan apa yang baru mereka pelajari ke dalam satu persoalan yang ada dalam kehidupan nyata. Sedangkan kreativitas adalah hasil belajar dalam kecakapan kognitif, sehingga untuk menjadi kreatif dapat dipelajari melalui proses belajar mengajar Slameto (2003:138).

Penilaian kreativitas bagi seorang siswa menurut Slameto (2003:145) didasarkan pada keaslian tingkah laku yang mereka laksanakan dalam banyak cara dan kesempatan dalam menghadapi berbagai situasi belajar. Disamping itu juga didasarkan pada kepekaan mereka terhadap pengertianpengertian tertentu serta penggunaan dalam hidupnya. Selain definisi di atas Zsikszentmihalyi dalam Anna Craf (2004:49) menyatakan "kreativitas adalah persoalan pemecahan masalah dan menemukan masalah ”.

Metode snow ball, Hisyam Zaini, dkk (2007) menyatakan bahwa strategi ini digunakan untuk mendapatkan jawaban yang dihasilkan dari diskusi siswa secara bertingkat. Dimulai dari kelompok kecil kemudian dilanjutkan dengan kelompok yang lebih besar sehingga pada akhirnya akan memunculkan dua atau tiga jawaban yang telah disepakati oleh siswa secara kelompok. Strategi ini akan berjalan dengan baik jika materi yang dipelajari menurut pemikiran yang mendalam atau menurut siswa untuk berpikir analisis bahkan mungkin sintesis. Materi yang bersifat factual, yang jawabannya sudah ada di dalam buku teks mungkin tidak tepat diajarkan dengan strategi ini.

Langkah-langkah dari model pembelajaran snow ball yaitu : (1) Sampaikan topik materi yang akan diajarkan. (2) Minta siswa untuk menjawab secara berpasangan (dua orang) (3) Setelah siswa yang bekerja berpasangan tadi mendapatkan jawaban, pasangan tadi digabungkan 
Upaya Mengembangkan Kreativitas Siswa Tunarungu Kelas VIII dalam Menyelesaikan Soal Matematika Dengan Model Pembelajaran Aktif Tipe Snow Ball Pada Pokok Bahasan Bangun Ruang Sisi Lengkung di SMPLB Keraton Tahun Pelajaran 2015/2016

dengan pasangan di sampingnya. Dengan ini terbentuk kelompok dengan empat orang. (4) Kelompok berempat ini mengerjakan tugas yang sama seperti dalam kelompok dua orang. Tugas ini dapat dilakukan dengan membandingkan jawaban kelompok dua orang dengan kelompok yang lain. Dalam langkah ini perlu ditegaskan bahwa jawaban kedua kelompok harus disepakati oleh semua anggota kelompok baru. (5) Setelah kelompok berempat ini selesai mengerjakan tugas, setiap kelompok digabungkan dengan satu kelompok yang lain. Dengan ini muncul kelompok baru yang anggotanya delapan orang. (6) Yang dikerjakan oleh kelompok baru ini sama dengan tugas pada langkah keempat di atas. Langkah ini dapat dilanjutkan sesuai dengan jumlah siswa atau waktu yang tersedia. (7) Masing-masing kelompok diminta menyampaikan hasilnya di depan kelas. (8) Pengajar akan membandingkan jawaban dari masing-masing kelompok kemudian memberikan ulasan-ulasan dan penjelasan-penjelasan secukupnya sebagai klarifikasi dari jawaban siswa.

Dalam pendekatan pembelajaran aktif ini siswa diharapkan mampu mengembangkan kreativitas dalam menyelesaikan soal matematika. Karena kreativitas itu merupakan kemampuan individu untuk menciptakan sesuatu hal yang baru dan berbeda. Kreativitas setiap siswa berbeda-beda, siswa yang memiliki kreativitas tinggi mampu belajar dengan baik, dapat menciptakan cara belajar dengan mudah serta mampu memahami, menyelesaikan soal-soal yang dihadapi dalam belajar sehingga berpengaruh terhadap prestasi belajar yang dicapai.

Menumbuhkan kreativitas belajar siswa tidak hanya pada saat kegiatan belajar mengajar di sekolah melainkan dapat juga dilakukan saat belajar di rumah. Pengembangan kreativitas dalam belajar tumbuh dari kemampuan dalam diri individu atau bakat yang dimiliki seseorang dan dorongan orang tua yang membantu anak saat belajar di rumah. Proses 
Sugiyana

yang termasuk dalam kreativitas adalah membuat sebuah ide yang dapat mengembangkan daya pikir anak dalam menyelesaikan soal - soal.

\section{Metode Penelitian}

\section{Pendekatan dan Jenis Penelitian}

Penelitian ini merupakan Penelitian Tindakan Kelas (PTK), yaitu upaya perbaikan pelaksanaan praktek pendidikan oleh seorang atau sekelompok pengajar dengan melakukan tindakan-tindakan dalam pembelajaran berdasarkan refleksi mengenai hasil tindakan tersebut Elliot, (Wiraatmadja, 2005:20)

Penelitian ini menggunakan pendekatan tindakan sekolah yaitu bentuk pembelajaran yang bersifat reflektif untuk memperbaiki kondisi pembelajaran dan meningkatkan kemantapan rasional dari tindakan melaksanakan tugas dengan proses pengkajian berdaur, yaitu merencanakan, melakukan tindakan, mengamati, dan refleksi (Winardi, $2004: 6)$.

Menurut Arikunto, dkk (2011:74) setiap siklus pada penelitian tindakan terdiri dari tahapan-tahapan, yaitu: (1) perencanaan (planning), (2) pelaksanaan tindakan (acting), (3) pengamatan (observasi), (4) refleksi (reflecting).

\section{Lokasi Penelitian}

Penelitian ini dilaksanakan pada semester 1 yaitu antara bulan Februari 2016 sampai bulan Maret 2016 pada tahun pelajaran 2015/2016. Tempat penelitian tindakan kelas ini dilakukan di Sekolah Menengah Luar Biasa Bagian Tunarungu (SMPLB/B) Keraton Martapura. Pemilihan tempat tersebut didasarkan pada pertimbangan sebagai berikut :

a. SMPLB/B Keraton Martapura merupakan tempat tugas mengajar bagi peneliti.

b. Untuk memasukkan unsur-unsur pembaruan dalam sistem pembelajaran anak tunarungu di SMPLB/B) Keraton Martapura. 
Upaya Mengembangkan Kreativitas Siswa Tunarungu Kelas VIII dalam Menyelesaikan Soal Matematika Dengan Model Pembelajaran Aktif Tipe Snow Ball Pada Pokok Bahasan Bangun Ruang Sisi Lengkung di SMPLB Keraton Tahun Pelajaran 2015/2016

c. Untuk meningkatkan profesionalitas guru di SMPLB/B) Keraton Martapura. Subjek dalam penelitian ini adalah siswa tunarungu kelas VIII Tunarungu SMPLB/B) Keraton Martapura yang berjumlah 6 orang dengan rincian 4 orang siswa laki-laki dan 2 orang siswi perempuan

\section{Skenario Tindakan}

Sebagaimana prosedur penelitian tindakan kelas, maka dilaksanakanlah penelitian tindakan kelas ini dengan langkah-langkah (a) perencanaan, (b) pelaksanaan tindakan, (c) observasi dan evaluasi dan (d) refleksi.

\section{Data dan Cara Pengumpulan Data}

a. Data : Jenis data yang disajikan dalam penelitian ini adalah data kuantitatif dan data kualitatif. Data kuantitatif berupa nilai tes siswa, sedangkan data kualitatif berupa observasi kegiatan siswa dan guru.

b. Cara Pengumpulan Data : Data digali dan dikumpulkan dari kegiatan guru mengajar, kegiatan belajar siswa dan hasil tes akhir pada masing-masing pertemuan.

c. Perhitungan persentasi aktifitas guru dalam kegiatan penyusunan rancangan pembelajaran dengan menggunakan rumus sebagai berikut :

$$
P=\frac{\mathrm{f}}{\mathrm{N}} \times 100 \%
$$

Keterangan : (Sudijono : 2003)

$\mathrm{P} \quad=$ angka persentasi

$\mathrm{f} \quad=$ frekwensi

$\mathrm{N}=$ number of cases (jumlah frekuensi)

Hasil persentasi aktivitas belajar siswa dapat dikatagorikan pada tabel 1 sebagai berikut : 
Tabel 1 : Kategori Penilaian Aktivitas Belajar Siswa

\begin{tabular}{|c|c|}
\hline Rentang Persentasi & Kategori Penilaian \\
\hline $85 \%-100 \%$ & baik sekali \\
\hline $70 \%-84 \%$ & Baik \\
\hline $55 \%-69 \%$ & Cukup \\
\hline $40 \%-54 \%$ & Kurang \\
\hline $0 \%-39 \%$ & Kurang sekali \\
\hline
\end{tabular}

Perhitungan hasil penyusunan rancangan pembelajaran dan simulasi dengan menggunakan rumus sebagai berikut :

$$
P=\frac{\mathrm{jr}}{\mathrm{Ni}} \times 100
$$

Keterangan :

$$
\begin{array}{ll}
\mathrm{P} & =\text { angka persentasi } \\
\mathrm{jr} & =\text { Jumlah nilai riil } \\
\mathrm{Ni} & =\text { Jumlah nilai ideal }
\end{array}
$$

Hasil persentasi proses belajar mengajar dapat dilihat pada tabel 2 sebagai berikut :

Tabel 2 : Kategori Hasil Belajar Siswa

\begin{tabular}{|c|c|}
\hline Rentang Persentasi & Kategori Hasil Belajar Siswa \\
\hline $76 \%$ s.d. $100 \%$ & baik sekali \\
\hline $56 \%$ s.d. $75 \%$ & Baik \\
\hline $26 \%$ s.d. $55 \%$ & Cukup \\
\hline $0 \%$ s.d. $25 \%$ & Kurang \\
\hline
\end{tabular}

\section{Indikator Keberhasilan Belajar Siswa}

Seorang siswa dinyatakan tuntas apabila ia telah memenuhi Kreteria Ketuntasan Minimal (KKM) yang didapat dengan memberikan point pada setiap kreteria yang ditetapkan. KKM yang telah ditetapkan sekolah sebesar $\geq 60,25$ untuk individu yang dikatakan tuntas. Sedangkan untuk ketuntasan klasikal sekolah menetapkan $\geq 80 \%$ dari jumlah seluruh siswa yang tuntas.

Kriteria ketuntasan belajar yang ditetapkan oleh pihak sekolah tempat penelitian untuk mata pelajaran matematika adalah sebagai berikut: 
Upaya Mengembangkan Kreativitas Siswa Tunarungu Kelas VIII

dalam Menyelesaikan Soal Matematika Dengan Model Pembelajaran Aktif

Tipe Snow Ball Pada Pokok Bahasan Bangun Ruang Sisi Lengkung

di SMPLB Keraton Tahun Pelajaran 2015/2016

a. Daya serap individual

Siswa dikatakan tuntas jika mencapai skor $\geq 60,25$

b. Suatu kelas dikatakan tuntas apabila minimal $80 \%$ dari siswa dikelas mencapai skor $\geq 60,25$

\section{Hasil dan Pembahasan}

\section{Kondisi Sekolah}

SMPLB Keraton didirikan oleh Yayasan Pendidikan Sekolah Luar Biasa (YPSLB) Keraton Martapura pada 17 Juli Tahun 1998 dengan SK. Kakanwil Dikbud Provinsi Kalimantan Selatan No:31/115.a3/PR/98, tanggal 25 April 1998. SMPLB Keraton Martapura berlokasi di Jalan Menteri Empat No. 25 RT. 12 RW.5 Kel. Sungai Paring, Martapura Kota, Kabupaten Banjar, Kalimantan Selatan. SMPLB Keraton Martapura merupakan salah satu sekolah yang melayani pendidikan khusus $A=$ Tunanetera, $B=$ Tunarungu, $C=$ Tunagrahita, $D=$ Tunadaksa, $C=$ Tunaganda dan Autisme, pada tahun pelajaran 2015/206 jumlah keseluruhan 37 siswa dengan 9 ruang kelas, 1 Ruang Kepala Sekolah, 1 Ruang Guru, 1 Ruang Tata Usaha. Ruang asesmen/program kekhususan sesuai dengan kebutuhan siswa, 1 R. perpustakaan, R. Keterampilan, 1 Gedung serbaguna, dan Wc Guru/WC Siswa. Permasalahan dalam penelitian ini adalah rendahnya nilai matematika siswa kelas VIII/B tunarungu SMPLB Keraton Martapura terutama dalam menjawab soal mateatika pada sub pokok bahasan mencari luas dan volume dari tabung, dan kerucut.

\section{Kegiatan Tindakan Kelas}

\section{a. Perencanaan Tindakan Kelas}

Peneliti pada tahap perencanaan atau persiapan adalah pada hari Selasa tanggal, 9 Pebruari 2016, peneliti melakukan pengamatan khusus saat pembelajaran Matematika maupun wawancara dengan guru dan wawancara dengan siswa. Pengamatan saat proses pembelajaran dilakukan 
sebanyak tiga kali. Kegiatan yang dilakukan untuk melaksanakan pembelajaran pada pertemuan 1 ini sebagai berikut: (a) Menyusun RPP Matematika Standar Kompetensi: 5. Menghitung luas dan volume dari tabung, dan kerucut serta penggunaannya dalam pemecahan masalah. Kompentensi Dasar 5.3 Menyelesaikan masalah yang berkaitan dengan luas dan volume dari tabung, dan kerucut di kelas VIII SMPLB Keraton Martapura pada semester 1 Tahun Pelajaran 2015/2016. (b) Menyiapkan bahan dan media berupa kertas berpetak. (c) Menyiapkan instrumen penilaian sebagai indikator. (c) Membuat format oberservasi untuk mengamati kegiatan guru dan siswa dalam pembelajaran.

\section{b. Pelaksanaan Tindakan Kelas}

Pelaksanaan tindakan kelas putaran I dilaksanakan pada hari Kamis, tanggal 11 Pebruari 2016 dimulai pada pukul 07.30 wita sampai dengan 09.00 wita. Pelaksanaan tindakan kelas pada pertemuan 1, 2 dan pertemuan 3 dengan langkah-langkah sebagai berikut: (a) Pra KBM $( \pm 5$ menit) yakni kesiapan alat dan bahan pembelajaran, dan mengkondisikan kelas yang siap belajar (b) Kegiatan Awal ( \pm 5 menit) yakni, (a) menanyakan kehadiran anak, mengadakan apersepsi, dan memberitahukan tujuan/indikator pembelajaran (a) Kegiatan Inti ( \pm 40 menit) yakni (b) guru memberikan penjelasan materi tentang menggambar bangun tabung dan kerucut serta, menghitung mencari luas dan volume dari tabung, dan kerucut. (c) siswa memperhatikan guru menjelaskan materi dan (d) guru memberikan kesempatan siswa untuk bertanya merefleksi pelajaran dan mencatat hal-hal penting.

\section{c. Hasil Pelaksanaan Tindakan Kelas Putaran I}

Pada putaran I ini dominasi guru masih tampak dominan karena guru masih banyak memberikan penjelasan pada siswa baik dalam menemukan rumus maupun menyelesaikan soal yang diberikan dalam pembelajaran. Selain itu guru kurang memberikan motivasi kepada siswa yang kurang berhasil serta guru kurang memberikan bimbingan bagi siswa yang belum paham mengenai materi yang telah diajarkan. Biasanya siswa 
Upaya Mengembangkan Kreativitas Siswa Tunarungu Kelas VIII dalam Menyelesaikan Soal Matematika Dengan Model Pembelajaran Aktif Tipe Snow Ball Pada Pokok Bahasan Bangun Ruang Sisi Lengkung di SMPLB Keraton Tahun Pelajaran 2015/2016

yang aktif dan kreatif adalah siswa yang memiliki kemampuan tinggi, siswa yang kemampuannya rendah cenderung hanya melihat hasil pekerjaannya teman.

Untuk mengetahui tingkat pengembangan kreativitas siswa dalam menyelesaikan soal pokok bahasan bangun ruang sisi lengkung, dapat dilihat dari hasil tes yang diberikan dalam tindakan kelas. Adapun indikator yang dijadikan sebagai patokan untuk menilai kemampuan siswa dalam berkreatif menyelesaikan soal adalah sebagai berikut:

1) Kemampuan siswa mengkonstruksi soal dalam model matematika.

2) Ketepatan penggunaan rumus dalam menyelesaikan soal yang dihadapi.

3) Kebenaran dalam proses perhitungan mencari jawaban.

Adapun hasil dari tindakan kelas putaran I dilihat dari banyaknya siswa dan jumlah soal yang diberikan maka siswa mampu mengkonstruksi soal dalam model matematika dengan benar mencapai $70.73 \%$. Siswa yang menggunakan rumus dengan tepat untuk menyelesaikan soal mencapai $60.98 \%$. Sedangkan siswa yang mampu melakukan proses perhitungan secara benar mencapai 65.85\%.

\section{d. Hasil Pelaksanaan Tindakan Kelas Putaran II}

Pelaksanaan tindakan kelas putaran II dilaksanakan pada hari Kamis, tanggal 25 Februari 2016 dimulai pada pukul 07.30 wita sampai dengan 09.00 wita. Dilihat dari hasil pengamatan tindakan kelas putaran II, pembelajaran tindakan kelas putaran II guru sudah mulai menunjukkan sikap adil, tanpa membeda-bedakan siswa dalam memberikan bimbingan dan arahan kepada siswa. Guru lebih sering keliling kelas untuk melihat siswa-siswanya dalam mengerjakan soal-soal yang diberikan. Hal ini juga sebagai cara untuk mengetahui kemampuan siswa dan membimbing siswa bila siswa kurang paham terhadap materi yang sedang dibahas. 
Dalam pembelajaran putaran II terlihat guru masih cukup dominan, tapi guru sudah mencoba mengurangi dalam memberikan penjelasan pada saat pembelajaran. Guru hanya menjelaskan hal-hal yang dianggap perlu saja, sehingga mendorong siswa untuk berpikir kreatif dan mandiri. Sedangkan motivasi yang diberikan guru agar siswa lebih giat belajar kelihatan lebih sering dilakukan. Guru juga memberikan tujuan pembelajaran, memberikan gambaran tentang inti materi pelajaran dan memberikan gambaran kegiatan yang akan dilakukan. Kegiatan pembelajaran sudah mulai lancar dan hasilnya mengalami peningkatan dibandingkan pada putaran sebelumnya.

Dalam putaran ini masih terdapat kekurangan dalam pengadaan alat peraga. Karena alat peraga yang ada hanya bisa dipakai oleh guru. Dari hasil wawancara dapat diketahui bahwa siswa tetap menyukai pembelajaran matematika dengan pembelajaran aktif tipe snow ball ini. Meskipun alat perga hanya satu, tapi siswa tetap antusias dalam mengikuti proses pembelajaran. Dalam putaran II ini, indikator yang dijadikan sebagai patokan untuk menilai kemampuan siswa berkreatif dalam menyelesaikan soal matematika masih sama seperti pada putaran I. Pembelajaran putaran II ini sudah mengalami peningkatan dibandingkan pada putaran sebelumnya. Adapun hasil dari tindakan kelas putaran II ini yaitu mengkonstruksi soal dalam model matematika mengalami peningkatan menjadi $75.00 \%$. Sedangkan ketepatan siswa dalam menggunakan rumus juga meningkat menjadi 90.50\%. Kemampuan siswa dalam proses perhitungan untuk mencari jawaban juga mengalami peningkatan menjadi $75.00 \%$.

\section{e. Hasil Pelaksanaan tindakan Kelas Putaran III}

Pelaksanaan tindakan kelas putaran III dilaksanakan pada hari Kamis, tanggal 10 Maret 2016 dimulai pada pukul 07.30 wita sampai dengan 09.00 wita. Dalam pembelajaran tindakan kelas putaran III diperoleh hasil bahwa tindakan guru sudah sesuai dengan harapan yaitu guru sudah memberitahukan tujuan pembelajaran, memberi gambaran umum tentang 
Upaya Mengembangkan Kreativitas Siswa Tunarungu Kelas VIII dalam Menyelesaikan Soal Matematika Dengan Model Pembelajaran Aktif Tipe Snow Ball Pada Pokok Bahasan Bangun Ruang Sisi Lengkung di SMPLB Keraton Tahun Pelajaran 2015/2016

materi yang akan dibahas serta memberi pertanyaan pada semua siswa tentang materi mencari luas bola. Hal ini dilakukan untuk mengetahui sejauh mana kemampuan siswa belajar matematika. Kegiatan pembelajaran sudah berjalan lancar dan hasilnya sudah mengalami peningkatan dibandingkan pada putaran sebelumnya. Hal ini karena guru sudak menikmati proses pembelajaran menggunakan metode pembelajaran aktif tipe snow ball.

Perhatian siswa dalam pembelajaran sudah terfokus. Siswa sudah merespon penjelasan guru tentang materi pelajaran yang disampaikan pada putaran III ini yaitu mencari volume tabung, kerucut, dan bola. Pembelajaran tidak lagi didomonasi oleh guru. Hal ini tampak dari siswa yang mengerjakan soal yang diberikan guru, menjawab pertanyaan guru/menngerjakan soal ke depan kelas, dan mengajukan pertanyaan pada guru. Bimbingan guru untuk memudahkan siswa dalam menyelesaikan soalsoal latihan sudah merata karena guru lebih sering keliling kelas. Sehingga tampak adil dan siswa antusias dalam proses pembelajaran aktif ini. Pada pembelajaran putaran III sudah mengalami peningkatan dibandingkan dari putaran sebelumnya. Adapun hasil dari tindakan kelas putaran III ini yaitu kemampuan siswa mengkonstruksi soal dalam model matematika meningkat menjadi $78.05 \%$. Sedangkan ketepatan siswa dalam menggunakan rumus meningkat mencapai $92.68 \%$. Sedangkan kemampuan siswa dalam proses perhitungan untuk mencari jawaban meningkat mencapai $87.80 \%$. Hal ini menunjukkan bahwa proses pembelajaran menggunakan pembelajaran aktif tipe snow ball dapat meningkatkan kreativitas siswa dalam menyesaikan soal matematika sehingga mengakibatakan peningkatan pada prestasi belajar siswa.

\section{Pembahasan Hasil Penelitian}

Tujuan utama dari penelitian tindakan kelas ini adalah untuk meningkatkan pengembangan kreativitas siswa dalam menyelesaikan soal 
matematika pada pokok bahasan bangun ruang sisi lengkung. Untuk mengetahui tingakat pengembangan kreativitas siswa dalam menyelesaikan soal tersebut, dapat dilihat dari hasil tes yang diberikan tiap tindakan kelas. Adapun indikator yang dijadikan sebagai patokan untuk menilai apakah kemampuan siswa mengembangkan kreativitas dalam menyelesaikan soal matematika mengalami peningkatan atau tidak adalah sebagai berikut:

a. Kemampuan siswa mengkonstruksi soal dalam model matematika.

b. Ketepatan penggunaan rumus dalam menyelesaikan soal yang dihadapi.

C. Kebenaran dalam proses perhitungan mencari jawaban.

Dari putaran I sampai dengan putaran III kreativitas siswa menyelesaikan soal bangun ruang sisi lengkung dalam pembelajaran matematika mengalami peningkatan. Hal ini dapat dilihat dari tabel 3 dan gambar 1 grafik hasil tindakan sebagai berikut:

Tabel 3 : Prosentase Hasil Peningkatan Pengembangan Kreativitas Siswa Menyelesaikan Soal Pada Bangun Ruang Sisi Lengkung

\begin{tabular}{|c|c|c|c|}
\hline Tindakan & $\begin{array}{c}\text { Konstruksi Soal dalam } \\
\text { Model Matematika }\end{array}$ & $\begin{array}{c}\text { Penggunaan } \\
\text { Rumus }\end{array}$ & $\begin{array}{c}\text { Proses } \\
\text { Perhitungan }\end{array}$ \\
\hline Putaran I & $70.73 \%$ & $60.98 \%$ & $65.85 \%$ \\
\hline Putaran II & $75.00 \%$ & $90.50 \%$ & $75.00 \%$ \\
\hline Putaran III & $78.05 \%$ & $92.68 \%$ & $87.80 \%$ \\
\hline
\end{tabular}

Gambar 1 : Grafik Peningkatan Kreativitas Siswa Menyelesaikan Soal Bangun Ruang Sisi Lengkung

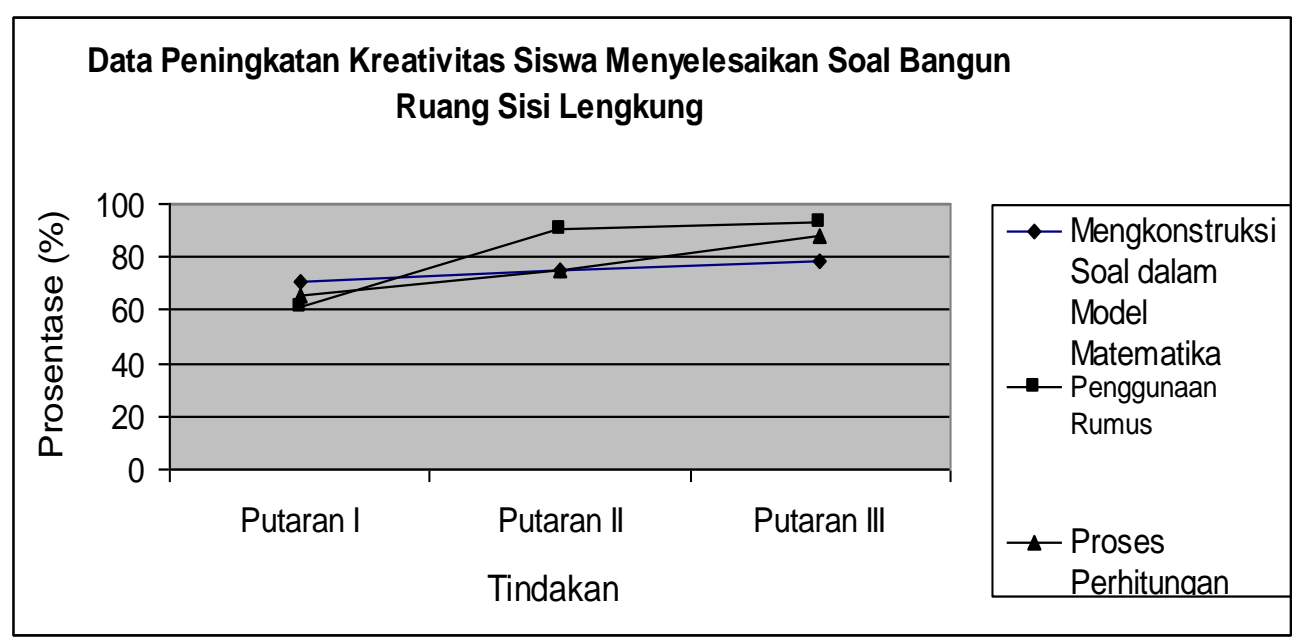


Upaya Mengembangkan Kreativitas Siswa Tunarungu Kelas VIII dalam Menyelesaikan Soal Matematika Dengan Model Pembelajaran Aktif Tipe Snow Ball Pada Pokok Bahasan Bangun Ruang Sisi Lengkung di SMPLB Keraton Tahun Pelajaran 2015/2016

\section{Refleksi Hasil Penelitian}

Dari putaran I sampai dengan putaran III kreativitas siswa menyelesaikan soal bangun ruang sisi lengkung dalam pembelajaran matematika mengalami peningkatan Berdasarkan dari tabel dan grafik diatas dapat dikemukakan hal-hal sebagai berikut:

a. Pengembangan kreativitas siswa dalam menyelesaikan soal bangun ruang sisi lengkung, dapat dilihat dari kemampuan siswa dalam mengkonstruksi soal dalam model matematika, ketepatan penggunaan rumus untuk menyelesaikan soal, kebenaran dalam proses perhitungan untuk mencari jawaban terus meningkat dari tindakan demi tindakan.

b. Peningkatan kreativitas siswa menyelesaikan soal bangun ruang sisi lengkung dalam hal kemampuan mengkonstruksi soal pada akhir tindakan mencapai $78.05 \%$, ketepatan penggunaan rumus untuk menyelesaikan soal mencapai $92.68 \%$, dan kemampuan dalam proses perhitungan untuk mencari jawaban mencapai $87.80 \%$.

c. Dari uraian di atas menunjukkan bahwa pengembangan kreativitas siswa dalam menyelesaikan soal matematika menggunakan pembelajaran aktif tipe snow ball mengalami peningkatan dari setiap tindakan dilihat dari kemampuan mengkonstruksi soal dalam model matematika, ketepatan penggunaan rumus untuk menyelesaikan soal, dan kemampuan proses perhitungan untuk mencari jawaban

d. Hasil belajar atau prestasi siswa merupakan penilaian, hasil usaha dari suatu kegiatan belajar yang dinyatakan dalam bentuk simbol, angka maupun huruf yang mencerminkan hasil yang sudah dicapai anak pada rentang waktu tertentu. Dengan adanya belajar akan terdapat proses perubahan dalam pemikiran serta tingkah laku. Pada proses pembelajaran penguasaan materi pelajaran yang dipelajari ditunjukkan dengan nilai tes atau angka yang diberikan oleh guru. 
e. Hasil belajar siswa didapat dari nilai latihan soal-soal yang diberikan guru pada tiap tindakan. Pada penelitian tindakan kelas ini prestasi belajar siswa meningkat disetiap putaran. Dari hasil penelitian pada tindakan kelas putaran I nilai rata-rata kelas adalah 83.4, pada putaran II nilai rata-rata kelas adalah 87.5, dan pada putaran III nilai rata-rata kelas adalah 88.5

\section{Kesimpulan}

Berdasarkan hasil penelitian dan pembahasan serta analisis data yang diperoleh melalui penelitian tindakan kelas pada Upaya mengembangkan kreativitas siswa kelas VIII/B tunarungu dalam menyelesaikan soal matematika dengan model pembelajaran aktif tipe snow ball pokok bahasan bangun ruang sisi lengkung di SMPLB Keraton Tahun Pelajaran 2015/2016. Peningkatan pengembangan kreativitas siswa dalam menyelesaikan soal matematika dapat dilihat dari peningkatan beberapa aspek, antara lain :

1. Adanya peningkatan kemampuan siswa mengkonstruksi soal yang diberikan oleh guru ke dalam model matematika. Hal ini dapat dilihat dari data hasil tindakan kelas. Pada putaran I kemampuan siswa mengkonstruksi soal dalam model matematika mencapai $70.73 \%$, sedangkan pada putaran II mencapai $75.00 \%$, dan pada putaran III mencapai $78.05 \%$.

2. Adanya peningkatan ketepatan penggunaan rumus untuk menyelesaikan soal yang diberikan. Hal ini dapat dilihat dari data hasil tindakan kelas. Pada putaran I peningkatan ketepatan penggunaan rumus untuk menyelesaikan soal mencapai $60.98 \%$, sedangkan pada putaran II mencapai $90.50 \%$, dan pada putaran III mencapai $92.68 \%$.

3. Adanya peningkatan kemampuan dalam proses perhitungan untuk mencari jawaban soal yang diberikan, hal ini dapat di lihat dari data hasil tindakan kelas yang dilakukan. Dari data hasil tindakan 
Upaya Mengembangkan Kreativitas Siswa Tunarungu Kelas VIII dalam Menyelesaikan Soal Matematika Dengan Model Pembelajaran Aktif Tipe Snow Ball Pada Pokok Bahasan Bangun Ruang Sisi Lengkung di SMPLB Keraton Tahun Pelajaran 2015/2016

kelas putaran I kemampuan siswa dalam proses perhitungan soal yang diberikan mencapai $65.85 \%$, sedangkan pada putaran II mencapai $75.00 \%$, dan pada putaran III mencapai $87.80 \%$.

\section{Daftar Pustaka}

Aisyah Nyimas, 2007. Pendekatan Pemecahan Masalah Matematika. Depdiknas. Dirjendikti. Jakarta

Arikunto, dkk. 2011. Penelitian Tindakan Kelas Jakarta: Bumi Aksara. , S. 2011. Dasar-Dasar Evaluasi Pendidikan. Edisi Revisi. Jakarta : PT. Bumi Aksara

Anonim, 1997. KBM Bahasa Bagi Anak Tunarungu. Materi Pelatihan Konversi In Service Guru SLB-B. Jakarta : Bagian Proyek Peningkatan Mutu SLTP

Depdiknas. 2006. Undang-Undang Republik Indonesia Nomor 20 tahun 2003 Tentang Sistem Pendidikan. Jakarta: Sekjen Depdinas

Bandi Delphie, 2007. Pembelajaran Anak Tunagrahita, Suatu Pengantar dalam Pendidikan Inklusi. Cetakan kedua. Refika Aditama

Cliffs, 2007. Matematika Dasar dan Pra - Aljabar. Pakar Raya. Bandung.

Craft, Anna. 2003. Membangun Kreativitas Anak. Jakarta : Inisiasi Press

Permanarian Somat \& Tati Herawati.2004. Ortopedagogik Anak Tunarungu Departemen Pendidikan Dan Kebudayaan Direktorat Jendral Pendidikan Tinggi Jakarta: Proyek Pendidikan Tenaga Guru

Slameto. 2003. Belajar dan Faktor-Faktor yang Mempengaruhi. Jakarta : Rineka Cipta

Wiriaatmadja, Rochiati. 2005. Metode Penelitian Tindakan Kelas. Bandung : Remaja Rosdakarya

Winardi, 2004. Penelitian Tindakan Kelas. Jakarta : Unversitas Terbuka

Zaini, Hisyam dkk. 2007. Strategi Pembelajaran Aktif. Yogyakarta : CTSDUIN Yogyakarta

\section{Sugiyana}

SMPLB Keraton Martapura

E-mail: Sugiyana.sm@gmail.com 